\title{
From the ICL2012 Conference Chair
}

\author{
http://dx.doi.org/10.3991/ijoe.v9i1.2474
}

This special issue includes selected papers from the joint conferences

\section{International Conference on Interactive Collaborative Learning (ICL2012) and 41. International Conference on Engineering Pedagogy}

26-28 September 2012, Villach, Austria, http://www.icl-conference.org

The conference was dedicated to the 40th anniversary of the founding of the International Society of Engineering Education (IGIP).

During the conference also the 80th Birthday of the founder of IGIP, Adolf Melezinek - the father of Engineering Pedagogy as a scientific subject, was celebrated with an honorary colloquium. It was a pleasure for us to welcome distinguished international guests:

- Hans Hoyer, Secretary General International Federation of Engineering Education Societies (IFEES)

- Stephanie Farrel, Vice-President American Society of Engineering Education (ASEE)

- Manuel Castro, President Institute of Electrical and Electronics Engineers (IEEE), Education Society

- Russ Meier, Vice-President IEEE Education Society

- Victor Schutz, former IEEE President

- N. V. Ratnalikar, President Indian Engineering Education Foundation (EEF)

- David Guralnick, President International E-Learning Association (IELA)

- Doru Ursutiu, President International Association of Online Engineering (IAOE)

- Ivan Esparragoza, Vice-President Latin American and Caribbean Consortium of Engineering Institutions (LACCEI)

- Andras Szucs, Secretary General European Distance and E-Learning Network (EDEN)

Furthermore Rectors from some European Universities were present.

This interdisciplinary conference was again focused on the exchange of relevant trends and research results as well as the presentation of practical experiences gained while developing and testing elements of interactive learning.

The special motto of this year's ICL was “Collaborative Learning and New Pedagogical Approaches in Engineering Education”. We received near 400 paper submission from all over the world. Finally about 200 presentations were selected to appear in the conference program. On the three conference days we had 385 participants from 61 countries from all continents. 
International outstanding experts gave keynote presentations:

- Hans Hoyer, Secretary General of the International Federation of Engineering Education Societies (IFEES), USA: “Global Partnerships in Engineering Education”;

- Sabina Jeschke, Director TeachING-LearnING.EU, RWTH Aachen, Germany: "VisioneerING - Future Trends in Engineering Education"

- Russ Meier, Vice-President of the IEEE Education Society, USA: “Global Trends in Engineering Education”

- Jose Carlos Marques dos Santos, Rector University of Porto, Portugal: "New challenges in engineering education and the answer of University of Porto"

- Djamshid Tavangarian, University of Rostock, Germany: "Is Social Online Based Learning the Cure for Knowledge Poverty?”

- Steve Wheeler, Plymouth University, UK: “Learning 3.0 and the Smart eXtended Web"

During the conference IGIP at the first time awarded international scientific personalities for outstanding achievements in Engineering Education and Pedagogy:

With the Nicola-Tesla-Chain were awarded:

- Adolf Melezinek, Austria

- Rob Reilly, USA

The Adolf-Melezinek-Meritorious-Service Award received:

- Viacheslav Prichodko, Russia

- Victor Schutz, USA

- Hartmut Weidner, Austria

The honorable title "IGIP Senior Member" received:

- Dana Dobrovska, Czech Republik

- Vasiliy Ivanov, Russia

- Eleonore Lickl , Austria

- Larisa Petrova, Russia

- Norbert Kraker, Austria

As “International Engineering Educator - Ing.Paed.IGIP” were awarded:

- Ivan Esperragoza

- Stephanie Farrell

- Hans Hoyer

- Vera Melezinek

- Russ Meier

- Andras Szucs 
Furthermore the IGIP Young Scientist Award went to:

- Ramona Oros , Transilvania University of Brasov, Romania With a work on: Educational Studies of the Use of a WiTAG System

- Swetlana Rusina, Belgorod State Technological University, Russian Federation With a work on: Gender Characteristics of Graduates - Engineers

- Tiago Andrade, Faculdade de Engenharia, University Porto, Portugal With a work on: Project Based Learning Activities in Engineering Education

The next ICL2013 conference will be held in Kazan, Russia from 25-27 September 2013.

Michael E. Auer

Conference Chair 